\title{
Intersyngenic Variations in the Esterases of Bacterized Paramecium aurelia
}

\author{
Sally Lyman Allen, ${ }^{1}$ Bruce C. Byrne, ${ }^{2}$ and Donald L. Cronkite ${ }^{2}$
}

Received 15 July 1970-Final 12 Nov. 1970

The esterase isozymes were surveyed in bacterized stocks representative of all 14 syngens of Paramecium aurelia by starch gel electrophoresis. The properties of substrate specificity and independent variation of particular isozymes permit the ordering of the differences observed among stocks. Differences can arise from several sources: bacterial variation, intrasyngenic variation, and intersyngenic variation. Bacterial esterases tend to be found in certain zonal areas (see Rowe et al., 1971) and produce minor stock differences, which are erratic in their distribution. Unlike the situation found in Tetrahymena pyriformis, major intrasyngenic variations are rare in $\mathrm{P}$. aurelia except in syngen 2. This lack of intrasyngenic variation is significant in view of the wide differences in geographic origin and micronuclear chromosome numbers among stocks within a syngen. It suggests that certain esterase genotypes must be under stringent selection within a syngen. The lack of intrasyngenic variation permits assessment of intersyngenic relationships. Syngens differ in a complex way from each other, suggesting that several gene differences may be involved. The syngens can be classified on the basis of their esterases. Syngens which have been shown to be more closely related in terms of crossmating, breeding systems, and other criteria tend to be more similar in their esterase isozymes. The isozyme technique confirms relationships previously suggested among syngens and offers the promise of eventual assessment of evolutionary distances among syngens. However, establishment of these relationships will be clearer in the absence of bacteria.

\section{INTRODUCTION}

Evolution in the ciliated protozoa has resulted in the diversification of morphologically similar cells into a number of reproductively isolated groups, which have been lumped

\footnotetext{
Supported by a Research Grant, GM-15879, from the National Institute of General Medical Sciences, U.S. Public Health Service

1 Departments of Botany and Zoology, The University of Michigan, Ann Arbor, Michigan.

${ }^{2}$ Department of Zoology, Indiana University, Bloomington, Indiana.
} 
together by taxonomists into single species because of their morphological similarity. Examples of such species complexes are Tetrahymena pyriformis and Paramecium aurelia. Each of these species complexes contains populations of animals between which gene flow does not normally occur. From the genetic point of view, these breeding groups are different biological species. They have been referred to as syngens by Sonneborn (1957). We have been concerned with the extent of isozyme variation

Table I. Stocks of $P$. aurelia

\begin{tabular}{|c|c|c|c|c|c|}
\hline Syngen & Stocks & $\begin{array}{l}\text { Geographic } \\
\text { origin }\end{array}$ & Syngen & Stocks & $\begin{array}{c}\text { Geographic } \\
\text { origin }\end{array}$ \\
\hline 1 & $\begin{array}{r}P \\
147 \\
175 \\
220 \\
257 \\
285 \\
320 \\
337\end{array}$ & $\begin{array}{l}\text { Maryland } \\
\text { Japan } \\
\text { Peru } \\
\text { Hawaii } \\
\text { Mexico } \\
\text { California } \\
\text { Poland } \\
\text { U.S.S.R. }\end{array}$ & 5 & $\begin{array}{r}63 \\
210 \\
236 \\
311 \\
166 \\
309 \\
326\end{array}$ & $\begin{array}{l}\text { Indiana } \\
\text { Ohio } \\
\text { Nevada } \\
\text { Australia } \\
\text { India } \\
\text { Thailand } \\
\text { Kenya }\end{array}$ \\
\hline 2 & $\begin{array}{r}50 \\
71 \\
72 \\
91 \\
149 \\
160 \\
179 \\
193 \\
206 \\
234 \\
305\end{array}$ & $\begin{array}{l}\text { Oregon } \\
\text { Indiana } \\
\text { Texas } \\
\text { Pennsylvania } \\
\text { Florida } \\
\text { Minnesota } \\
\text { Chile } \\
\text { Germany } \\
\text { Norway } \\
\text { Japan } \\
\text { Arizona }\end{array}$ & 7 & $\begin{array}{r}38 \\
227 \\
253 \\
325 \\
31 \\
138 \\
214 \\
276 \\
299 \\
327 \\
330\end{array}$ & $\begin{array}{l}\text { Florida } \\
\text { Florida } \\
\text { Florida } \\
\text { Florida } \\
\text { Maryland } \\
\text { Florida } \\
\text { Florida } \\
\text { Texas } \\
\text { Panama } \\
\text { Florida } \\
\text { Georgia }\end{array}$ \\
\hline 3 & $\begin{array}{r}\mathrm{M} \\
79 \\
152 \\
261 \\
275\end{array}$ & $\begin{array}{l}\text { Maryland } \\
\text { New Jersey } \\
\text { Connecticut } \\
\text { Quebec } \\
\text { Alaska }\end{array}$ & 10 & $\begin{array}{l}204 \\
312 \\
317 \\
338 \\
223\end{array}$ & $\begin{array}{l}\text { Scotland } \\
\text { Germany } \\
\text { France } \\
\text { U.S.S.R. } \\
\text { Florida }\end{array}$ \\
\hline 4 & $\begin{array}{r}29 \\
32 \\
47 \\
51 \\
126 \\
139 \\
148 \\
163 \\
172 \\
173 \\
230 \\
280 \\
298 \\
315 \\
316 \\
329\end{array}$ & $\begin{array}{l}\text { Maryland } \\
\text { Maryland } \\
\text { California } \\
\text { Indiana } \\
\text { Florida } \\
\text { Florida } \\
\text { Japan } \\
\text { Pennsylvania } \\
\text { Peru } \\
\text { Chile } \\
\text { Australia } \\
\text { Virginia } \\
\text { Panama } \\
\text { Italy } \\
\text { Holland } \\
\text { Poland }\end{array}$ & $\begin{array}{l}11 \\
12\end{array}$ & $\begin{array}{l}306 \\
270 \\
273 \\
274 \\
209 \\
238 \\
321 \\
328\end{array}$ & $\begin{array}{l}\text { Texas } \\
\text { Florida } \\
\text { Louisiana } \\
\text { Louisiana } \\
\text { France } \\
\text { Madagascar } \\
\text { Mexico } \\
\text { Australia }\end{array}$ \\
\hline
\end{tabular}


within and between syngens in each species complex with the goal of obtaining information on evolutionary relationships. In the first paper of this series, we reported our observations on $T$. pyriformis. In this paper we turn to $P$. aurelia.

There are 14 breeding groups, or syngens, of $P$. aurelia. Morphologically similar, they vary in cell size, micronuclear chromosome number, the details of their breeding systems, mating-type and serotype inheritance, temperature tolerance, and geographic distribution (Sonneborn, 1957, 1958, 1966; Sonneborn et al., 1959; Rafalko and Sonneborn, 1959). According to Sonneborn, temperature is probably a major factor in influencing the range of the syngen within a continent. Some syngens have been found in two or more widely distributed continents and are probably worldwide in distribution (syngens $1,2,4,5,6,8$, and 13). Others are more restricted in distribution. Thus, syngen 3 has been collected in North America (Alaska, Canada, United States), syngen 9 in Europe, and syngen 14 (one stock only) in Australia. Syngens 7, 10, 11, and 12 have been found almost exclusively in certain southern states of the United States. A weak mating reaction occurs between syngens 1 and 3 or 7 and syngens 3 and 8 , a stronger reaction between syngens 1 and 5 ; the $F_{1}$ are viable but not the $F_{2}$ and backcross progeny. A strong mating reaction occurs between syngens 4 and 8 ; a few $F_{1}$ survive, but these have very low fertility. This low fertility is apparently due to wide differences in the numbers of micronuclear chromosomes between syngens. Recombination is rarely if ever observed in intersyngenic crosses.

Our approach was to compare the esterase isozymes of stocks in different syngens. Stocks within a syngen were selected from as widely different locales as possible with the hope of obtaining genetic variants. We used the techniques which have been successful for T. pyriformis (Allen and Weremiuk, 1971). What is the extent of variation between different stocks? Are the variations ordered with respect to syngen differences? And are the variations as extensive as those found for T. pyriformis?

\section{MATERIALS AND METHODS}

\section{Stocks}

The stocks used are listed in Table I. We selected those with the most diverse geographic origins as far as was possible. They were maintained at $27 \mathrm{C}$ in bacterized medium (Cerophyl rye grass or baked lettuce inoculated with Aerobacter aerogenes).

It is possible that in handling these stocks over the years some have become misclassified. Some of the variants we observed may not be real but due to misclassification. These are discussed more fully below.

\section{Growth of Cells for Extracts}

A minimum of 1 liter of a "cleared culture" of paramecia was used. These cultures were initiated from $10-15 \mathrm{ml}$ of a cleared tube population. The cells were concentrated in an oil-testing centrifuge, washed once with Dryl's solution (Dryl, 1959), and then further concentrated in a clinical centrifuge. The cells were disrupted by freezethawing, and the extracts were stored frozen until the day of use. Esterase activity is retained for at least 2 years in frozen extracts. 


\section{Electrophoretic Procedure}

Starch gel electrophoresis was carried out in essentially the same manner as that used for T. pyriformis (Allen, 1964; Allen et al., 1963). A gel was made containing 11.5\% hydrolyzed starch (Connaught Medical Laboratories) in $0.03 \mathrm{M}$ boric acid-tris buffer, $p \mathrm{H} 8.0$, and poured into lucite trays, $23 \mathrm{~mm}$ wide by $7 \mathrm{~mm}$ deep by $22.5 \mathrm{~cm}$ long (internal dimensions), covered with flexible lucite lids, using comparable pressure on each tray, and refrigerated until the following day. A Whatman No. 1 filter paper (10 $\mathrm{mm}$ wide by $7 \mathrm{~mm}$ deep) was then saturated with an extract, blotted dry, and inserted into a cut $9 \mathrm{~cm}$ from the cathodal end of the tray. Two filter papers were inserted on the right and left sides of each tray. Each tray was covered with Saran Wrap except for the ends, which were left exposed to filter paper wicks. Electrophoresis was carried out at $23 \mathrm{C}$ in the horizontal position using $8-10 \mathrm{v} / \mathrm{cm}$ for $4 \frac{1}{2}-5 \mathrm{hr}$ (the setting on the Heathkit power supply was kept at $300 \mathrm{v}$ throughout). The electrode buffer was 0.3 M boric acid-tris, $p \mathrm{H} 7.5$.

\section{Identification of Esterases}

After electrophoresis, the gels were removed from the trays, trimmed, and sliced with a modified Weck Hair Shaping Blade into slices $3 \mathrm{~mm}$ thick. The top $1 \mathrm{~mm}$ slice was discarded. The two lower slices were placed into enamel pans, always with the cut surfaces exposed on top. The bottom slice was incubated in $1 \mathrm{~mm} \alpha$-naphthyl butyrate and Fast Blue RR (1mg/ml) in $0.1 \mathrm{M}$ Sörensen's phosphate buffer, $p \mathrm{H}$ 6.5. The middle slice was incubated in $0.5 \mathrm{~mm} \alpha$-naphthyl propionate, $1 \mathrm{~mm}$ sodium taurocholate, and Fast Blue RR ( $1 \mathrm{mg} / \mathrm{ml})$ in $0.1 \mathrm{M}$ Sörensen's phosphate buffer, $p \mathrm{H} \mathrm{7.4.} \mathrm{The} \mathrm{gels} \mathrm{were}$ incubated for exactly $2 \mathrm{hr}$ at $30 \mathrm{C}$, rinsed with distilled water, and stored in $7 \frac{1}{2} \%$ acetic acid until photographed.

\section{RESULTS}

\section{Esterase Zymograms of Paramecium}

The total number of esterase isozymes from different bacterized stocks of $P$. aurelia that are resolved in starch gels with the two substrates is large. All the esterases split $\alpha$-naphthyl propionate, but only some can split both substrates. Some of these split both substrates equally, while others have a higher affinity for one of the substrates. Thus, there are four broad categories of esterases which we will arbitrarily designate types A, B, C, and D. Type A splits only $\alpha$-naphthyl propionate, type B has a greater affinity for $\alpha$-naphthyl butyrate, type $C$ has a greater affinity for $\alpha$-naphthyl propionate, and type D splits both substrates equally. We do not know, as yet, how these types correspond to the categories established in other species (see review by Beckman, 1966). Further information on substrate affinities and inhibitor studies will be required to make this comparison.

For the display of gels shown in Fig. 1, representative stocks were chosen for each syngen. The gels stained for $\alpha$-naphthyl butyrate are mirror images of the gels stained for $\alpha$-naphthyl propionate. Thus, in making comparisons between substrates, 
it should be noted that the right and left sides of the gels are reversed. Distances from the origin (or where the extract was inserted) are marked off in centimeters on the margins of the photographs. In lieu of assigning numbers to specific esterase isozymes, roman numerals are given for each centimeter area.

Table II summarizes the substrate affinities for the esterases found in different zonal areas. We will begin at the top of the photographs with zone XII. In this zone, there are one or more type $C$ esterases which vary in position in different syngens and which have a greater affinity for $\mathrm{P}$ ( $\alpha$-naphthyl propionate) than for $\mathrm{B}$ ( $\alpha$-naphthyl butyrate). Variable numbers of esterases with weak activity to both $\mathrm{P}$ and $\mathrm{B}$ are found in zonal areas IX-XI. These may become extremely numerous under certain conditions of growth where bacteria are present (see Fig. 2 of Allen and Gibson, 1971). Esterases with characteristic substrate preferences are found in zone VIII (in syngens 2 and 9). Zones III-VII contain type B esterases $(\mathrm{B}>\mathrm{P})$, zones IV-VI type A esterases $(\mathrm{P})$. The position of these two types of esterases varies in different syngens. For example, syngen 4 has a type $A$ esterase in region $V$ and possibly a second one in region IV and one or two type B esterases in regions III and IV. Regions I-III contain a variable number of esterases of different types, and later work has shown that some of these, along with some of the esterases in region IV, are bacterial in origin (Rowe et al., 1971). The bacterial esterases in regions I-III tend to be types B, C, or D.

\section{Intrasyngenic Variations}

One of the surprises of this survey was the lack of intrasyngenic variation observed for the esterase isozymes. Figure 2 compares the esterases of stocks within syngens $1,3,5$, 7, and 9, and Fig. 3 compares those of stocks within syngens 2, 4, 6, and 8. Only minor variations are observed among the stocks of syngens 1, 3, 5, 6, 7, and 9. Most variations that are observed are in regions where bacterial esterases have since been

Table II. Substrate Affinities of Esterases in Paramecium ${ }^{a}$

\begin{tabular}{|c|c|c|}
\hline $\begin{array}{c}\text { Cm from } \\
\text { origin }\end{array}$ & $\begin{array}{l}\text { Zonal } \\
\text { area }\end{array}$ & $\begin{array}{l}\text { Substrate } \\
\text { affinity }\end{array}$ \\
\hline-5 & XII & $\mathbf{P}>\mathbf{B}$ \\
\hline-4 & $\mathrm{XI}$ & \\
\hline-3 & $\mathrm{X}$ & Minor and variable $\mathrm{P}>\mathrm{B}$ \\
\hline-2 & IX & \\
\hline-1 & VIII & $\mathrm{B}>\mathbf{P}(2) \mathbf{P}(2,9)$ \\
\hline $\mathbf{0}$ & VII & $\mathrm{B}>\mathrm{P}$ \\
\hline+1 & VI & $\mathrm{P}(\mathrm{B}>\mathrm{P}, 8)$ \\
\hline+2 & $\mathrm{~V}$ & $\mathrm{P}(\mathrm{B}>\mathrm{P}, 8 ?)$ \\
\hline+3 & IV & $\mathrm{P}(\mathrm{B}>\mathrm{P}, 4)$ \\
\hline+4 & III & $\mathrm{P}+\mathrm{B}, \mathrm{P}>\mathrm{B}(\mathrm{B}>\mathrm{P}, 4 ?)$ \\
\hline+5 & II & $(\mathrm{B}>\mathrm{P})$ \\
\hline+6 & $\mathrm{I}$ & $\mathrm{B}>\mathrm{P}(\mathrm{P}>\mathrm{B}, 2)(\mathrm{P}>\mathrm{B}$ doublet, 8$)$ \\
\hline+7 & & \\
\hline
\end{tabular}

${ }^{a} \mathbf{P}=\alpha$-naphthyl propionate; $\mathbf{B}=\alpha$-naphthyl butyrate. 


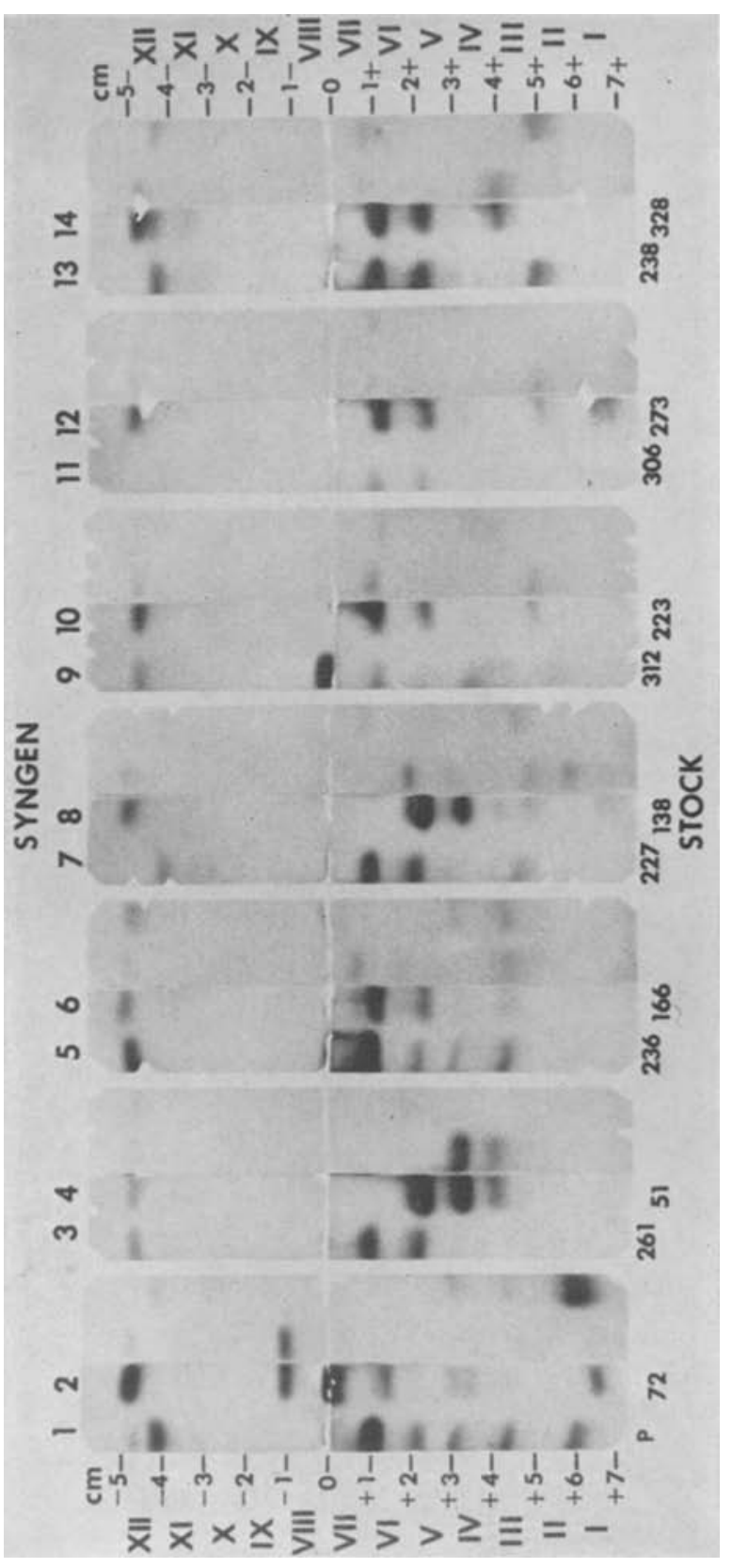

蒙.

至要

要曹

용

乙

这密定

훈

跣

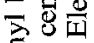

吾茷

영

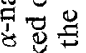

茫

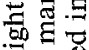

幽贾

记

:

\%

要

고표

焉

言热

i.

$\therefore$ 옹

焉焉

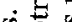

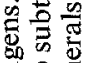

零号

$\pm 0$

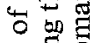

की

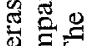

政

$\Xi . \Xi$

\%

o o

焉 운

类

움

总总范

동

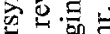

氖芯芯禹

- 웡

我急 
localized. Out of 16 stocks surveyed in syngen 4 , one was a variant. The variant is stock 173 from Chile, which has lost one of its type A esterases (region III) and has gained a new type B esterase in region VI. It is of interest that it is similar in appearance and migration to the type $B$ esterase found in syngen 8 . This stock could be misclassified, and perhaps it belongs in syngen 8 rather than 4 . Out of the seven syngen 8 stocks, one variant was observed. Stock 299 from Panama has a new type A esterase in region VII, and its type $A$ esterases in regions $I V$ and $V$ are less active (see Fig. 5a). This appears to be a real variant in syngen 8 since this stock has the type B esterases and two type $\mathrm{C}$ esterases (found in regions XII and I) characteristic of syngen 8 . Recent work with axenic stocks (bacteria-free stocks) has revealed that there may be two branches of stock 299. Axenic stock of 299 (both $\lambda$ and s) obtained from W. J. van Wagtendonk have the normal type A esterase, while an axenic stock of 299

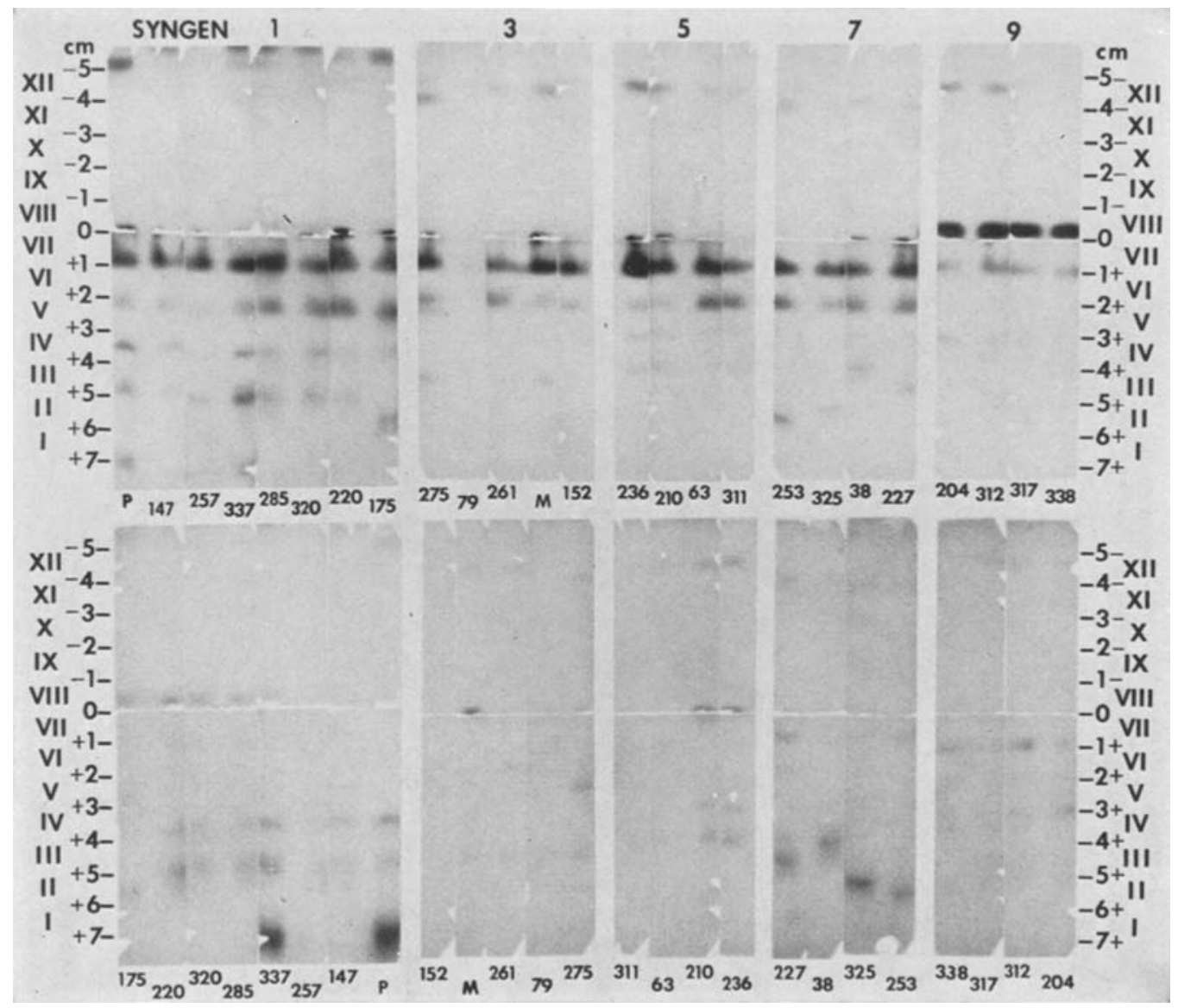

Fig. 2. Intrasyngenic variations in esterases of syngens $1,3,5,7$, and 9. Top: $\alpha$-naphthyl propionate. Bottom: $\alpha$-naphthyl butyrate. Electrophoresis was carried out for $5 \mathrm{hr}$ for syngen 1 , all others $4 \frac{1}{2} \mathrm{hr}$. 


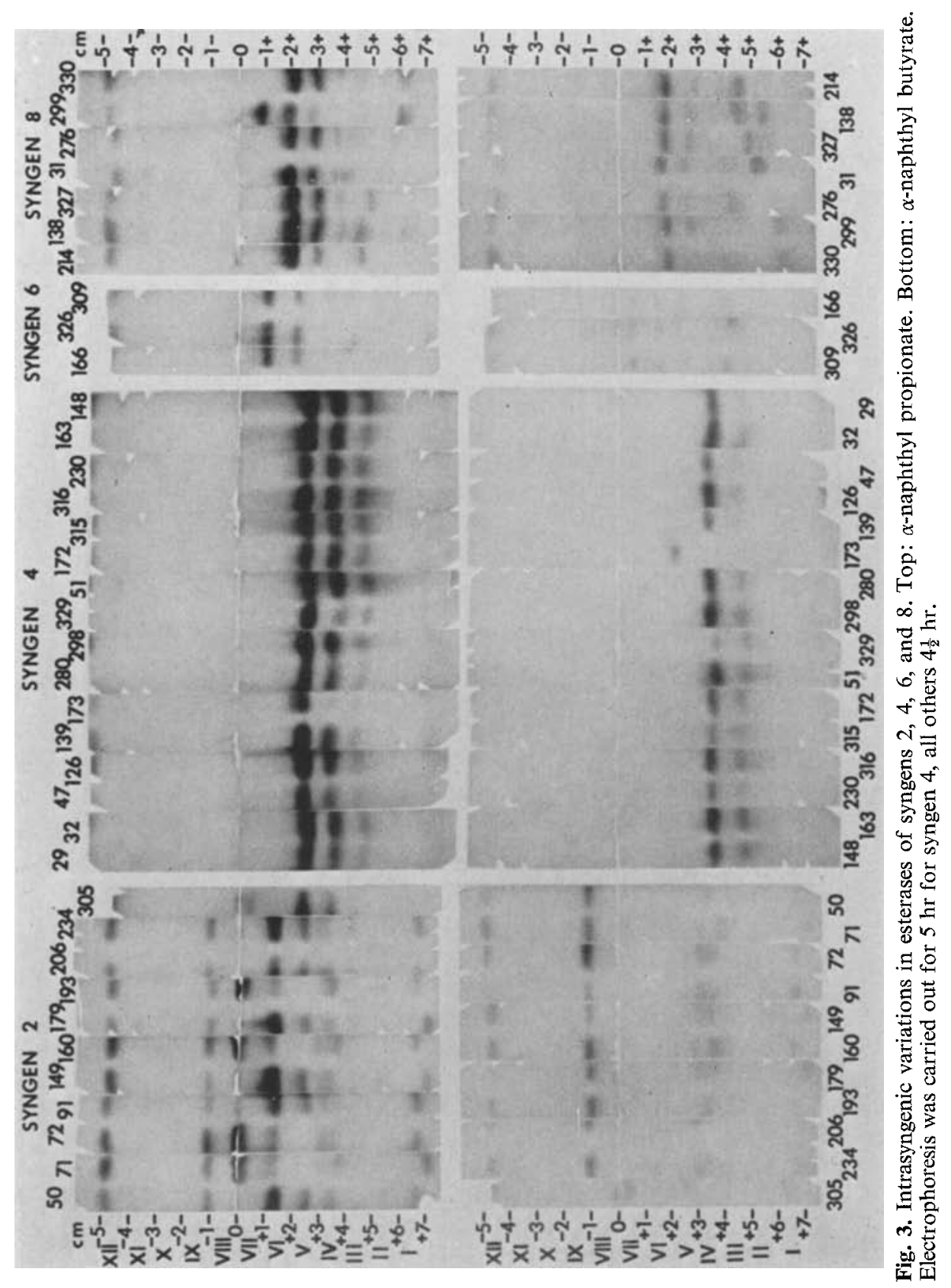


obtained from I. Gibson has the variant type A esterase. The electrophoretic pattern of the latter is identical to the pattern of the bacterized Indiana stock 299.

The most extensive variations were observed in syngen 2 . Stock 305 is an extreme variant in a number of respects. It is missing the type B esterase in region VIII which splits both substrates and which is found in all 10 of the other stocks, but it has an esterase with affinity for both substrates in region VII (see Fig. 5b). It also varies from the other stocks in regions IV-VII (see Fig. 5a). The other 10 stocks show two types of variation in different regions, and the stocks may be grouped into two classes with regard to each type of variation. Stocks 50, 91, 149, 179, 206, and 234 differ from stocks 71, 72, 160, and 193 around the origin and in regions V-VII in their type A esterases (Fig. 5a). A different grouping of stocks is found for variation in a type $C$ esterase in region I. Stocks 71,149 , and 179 have a form of this esterase which migrates more rapidly than the one in the other seven stocks (see Fig. 5c). The "alternative" nature of these variations suggests that independent segregation of at least two genes is occurring in these 10 stocks. If stock 305 does belong to syngen 2 , then additional genetic differences are implied. Syngen 2, therefore, stands out from the other syngens not only in showing intrasyngenic variation but in the extent of this variation. The differences among stocks suggest considerable local differentiation of the stocks in syngen 2. This situation appears to be unlike the situation in other syngens where a lack of local differentiation is implied even in stocks isolated from each other by vast geographic distances.

\section{Intersyngenic Variations}

Since intrasyngenic variation is not the rule (except for syngen 2), comparisons between syngens become possible.

The type A esterases of syngens 1, 3, 5, 7, 10,11,12, 13, and 14 are remarkably similar and are found in regions V and VI (Fig. 5a). The type A esterases of syngens $2,4,6,8$, and 9 differ from those of the other syngens in regions IV-VIII. This type of esterase is found in region VIII in syngen 9 , in regions IV-V in syngens 4 and 8 , and in three different positions in syngen 2 . One of the syngen 2 patterns is similar to that observed for syngen 6 .

The type B esterases of syngens $1,3,5,6,7,9,10,11,12,13$, and 14 are found in region VII (Fig. 5b). The type $\mathrm{B}$ esterase found in syngens 1,3 , and 5 varies slightly with the conditions of electrophoresis. If electrophoresis is carried out for $5 \mathrm{hr}$ (rather than $4 \frac{1}{2}$ ), it migrates very slowly to the cathode (see Fig. 2, syngen 1). Under slightly more alkaline conditions, it migrates very slowly to the anode (see Rowe et al., 1971; Allen and Gibson, 1971). It is apparently sensitive to very small differences in $p \mathrm{H}$, and this sensitivity was not recognized until recently. Syngen 6 has a slowly migrating anodal esterase of this type (under the electrophoretic conditions here and also in recent experiments). Syngens 7,13 , and 14 have a slightly faster esterase, and syngens 9,11 , and 12 a more rapidly migrating esterase $(+1 \mathrm{~cm})$. Syngen 10 appears to have a type B esterase that migrates between that of syngens 7-13-14 and that of syngens 9-11-12. Syngens 2, 4, and 8 have distinct type B esterases from the other syngens, and these are usually found in regions other than VII (exception: 305 in syngen 2). The 
usual type B esterase of syngen 2 is found in region VIII. Syngens 4 and 8 appear to have two type $B$ esterases, the more cathodal one being extremely active. (The weaker anodal B esterase is not seen in axenic stocks and is therefore questionable.) Syngen 8 has a "crisp" esterase of this type in region VI, and syngen 4 has a very active type B esterase in region IV. When $\alpha$-naphthyl butyrate is used as substrate, the type B esterases of syngens 2,4 , and 8 stand out in terms of their activity on the photographs (see Fig. 3).

In region XII there occurs a group of esterase isozymes which split both substrates $(P>B$, and thus type $C)$. Growth in bacterized medium tends to obscure the comparisons, but even so some differences that can be attributed to paramecia seem to exist among the syngens in the position of these esterases (see Figs. 4 and 5c). Some of the stocks of syngens 1 and 3 appear to have two isozymes (b and c), which vary in intensity in different stocks. Curiously, b but not $\mathrm{c}$ is found in some of the axenic stocks of syngen 1 . Whether $\mathrm{c}$ is bacterial in origin or is paramecial but induced by the presence of bacteria has not been determined. A similar situation seems to be found in some of the syngen 7 stocks where $\mathrm{c}$ and $\mathrm{d}$ are present in bacterized stocks. Syngens 2 , $4,5,6,9,10,12$, and 14 have b only, and syngens 11 and $13 \mathrm{c}$ only. Syngen 8 has esterase $a$, which migrates more rapidly than the fastest isozyme $b$ of syngen 1 . The difference in positions of esterases $a$ and $b$ is shown in the photographs of the gels which compare syngens 1 and 8 and syngens 4 and 8 (Fig. 4).

\section{Ordering of Variations with Respect to Syngen Differences}

At first glance, the esterase isozymes appear to have complex patterns. Yet, within the complexity there is order. There are different types of esterases in terms of substrate specificity, and each type varies independently in different syngens. This information can aid in determining which isozymes are "alternative forms" or homologous in different syngens. Thus, the differences between syngens can be ordered.

It has also helped to know that some of the variable esterases are due to bacteria and can be ignored for purposes of comparisons between syngens.

It would be relatively simple to assign a new stock to syngens $2,4,6,8$, or 9 on the basis of its esterase isozymes. If not in one of these five syngens, pinpointing which of the other nine it belongs to would be more difficult. But the choice could be narrowed down to only a few if several different types of esterase isozymes were examined. The game is played in Table III. Using the three types of esterases described in the preceding section, an unknown stock could be assigned to a specific syngen or group of syngens. For example, we could assign an unknown stock to syngen 11 if it had the type A esterase characteristic of syngens 1, 3, 5, 7, 10,11, 12, 13, 14, a type B esterase found about $1 \mathrm{~cm}$ toward the anode, and a type $\mathrm{C}$ esterase in the c position. We could not complete the identification if it belonged to syngens $1,3,5,7$, or 13, but we could narrow it down to either $1,3,5$ or 7,13 .

Of interest to us are the patterns of similarity among certain syngens. For example, syngens 4 and 8 bear more similarity to each other than to the rest of the syngens with regard to the type A esterase. Syngens 1, 3, and 5 are indistinguishable for all types 


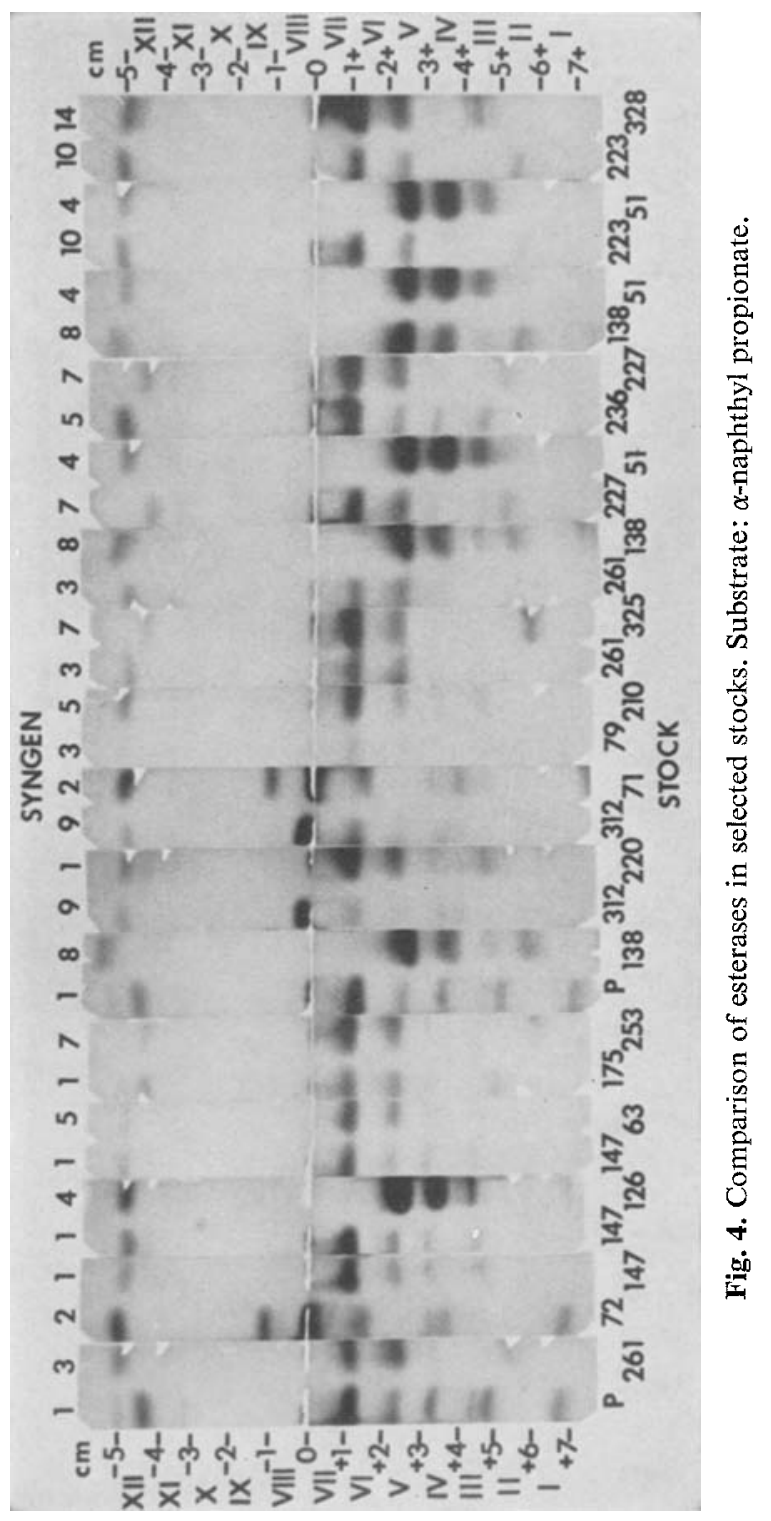


(until we understand better the nature of the types of variation that occur in zone XII).

We were also impressed that despite the fact that the syngens differ from each other in a complex way, there may emerge a restricted number of classes of variations. This suggests a restricted number of gene differences. The ordering of the syngens with respect to the three types of esterases (Table III) illustrates this point. Some syngens are separated from each other by differing in all three types of esterases (i.e., 1 vs. 8). Between other syngens only one difference separates them (i.e., 11 vs. 12). Perhaps if
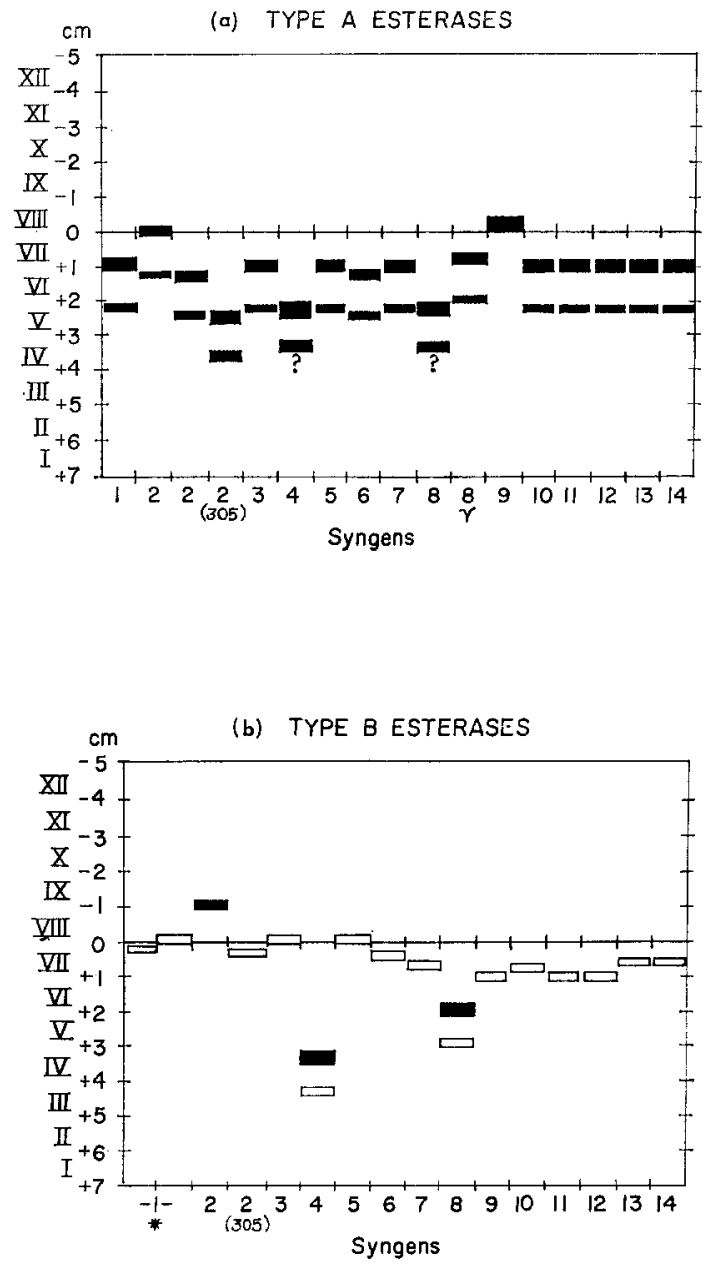

Fig. 5. Diagrams of three types of esterases in 14 syngens. (a) Type A esterases are specific for $\alpha$-naphthy] propionate. (b) Type B esterases have a higher affinity for $\alpha$-naphthyl butyrate than $\alpha$-naphthyl propionate. 
(c) TYPE C ESTERASES

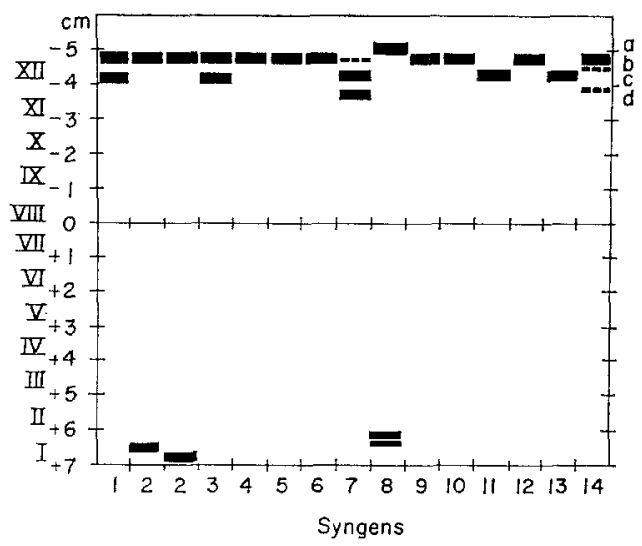

Fig. 5 (cont.). (c) Type $\mathrm{C}$ esterases have a higher affinity for $\alpha$-naphthyl propionate than $\alpha$-naphthyl butyrate.

Table III. The Game is the Number of the Syngen

\begin{tabular}{|c|c|c|c|}
\hline Type & Zone & Substrate & Syngen grouping \\
\hline A & IV-VIII & $\mathbf{P}$ & $(1,3,5,7,10,11,12,13,14)(9)(2)^{a}(6)(4,8)$ \\
\hline $\mathrm{B}$ & III-VIII & $\mathrm{B}>\mathrm{P}$ & $(1,3,5)(7,13,14)(10)(9,11,12,)(2)^{b}(6)(4)(8)$ \\
\hline $\mathrm{C}$ & XII & $\mathrm{P}>\mathrm{B}$ & 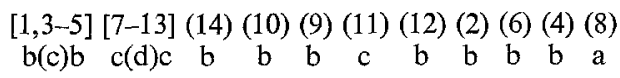 \\
\hline
\end{tabular}

a Three positions among 11 stocks.

b Two positions among 11 stocks.

we counted the number of differences, we might arrive at some measure of the evolutionary distances separating the syngens. This game will, however, be postponed until all the syngens have been surveyed in axenic medium.

\section{DISCUSSION}

The esterase isozymes which are resolved by starch gel electrophoresis are a collection of molecules which differ in their degree of genetic relatedness. This has been shown for T. pyriformis (see Allen, 1968). Thus, the products of several genes can be surveyed simultaneously. The properties of substrate specificity and the independent variation of particular molecular species permit the investigator to order the differences observed between stocks.

There are several sources of variation: bacterial, intrasyngenic, and intersyngenic. Variations due to bacteria as food source tend to be erratic. Some of the bacterial esterases have been identified (Rowe et al., 1971). However, it is also possible that 
growth in bacteria influences the activity of certain Paramecium esterases. And it is also possible that some of the bacterial symbionts housed by paramecia contribute esterases. Certainly, growth of paramecia in bacteria could result in inflating differences between stocks-if there were different contaminants present. On the other hand, it could depress differences-if similar bacterial contaminants were present. The stocks grown at Indiana University appear to contain few contaminants since differences between these stocks and the axenic stocks so far surveyed are on the whole minor (Allen and Gibson, 1971). However, stocks grown in bacteria can become so contaminated that syngen differences are obliterated (Allen and Gibson, 1971). Thus, caution is advised in using bacterized stocks. The results could be misleading. Comparisons should ideally be made between axenic stocks. Here, the differences among stocks are clearer, and indeed the results so far suggest better differentiation of syngens which have similar esterases.

Unlike our findings on T. pyriformis (Allen and Weremiuk, 1971), intrasyngenic variation is rare in $P$. aurelia. Tait $(1970 a)$ also found that the frequency of intrasyngenic variation was low in $P$. aurelia for four mitochondrial enzymes and soluble isocitrate dehydrogenase (a fifth mitochondrial enzyme-succinic dehydrogenaseshowed no variations among any stocks of the 14 syngens). In a survey of bacterized stocks, he found some variant stocks in syngens 2 and 9 for both types of isocitrate dehydrogenase and in syngens 2,4 , and 9 for $\beta$-hydroxybutyrate dehydrogenase. Single gene differences have been found for some of these variants (Tait, 1968, $1970 b$ ). Unlike our results, he did not find a greater degree of variation in syngen 2. No intrasyngenic variants were found for the other three enzymes. Conservatism might be expected for mitochondrial enzymes, but apparently it also applies to the esterases.

The lack of intrasyngenic variation even in stocks geographically distant is surprising in view of certain biological considerations. $P$. aurelia can either crossfertilize by conjugation of pairs of animals or it can self-fertilize by autogamy. Crossfertilization can lead to heterozygosity. Autogamy always results in homozygosity. The stocks used in our study had undergone autogamy and therefore were homozygous for all their genes. How frequent autogamy is relative to conjugation in nature is not known, but on the basis of several criteria, frequent inbreeding has been suspected (Sonneborn, 1957). Considerable local differentiation of populations would therefore be expected. Indeed, wide differences in micronuclear chromosomes in different stocks within a syngen were found and the fertility of outcrosses was considerably lower than that of crosses within a population (Kościuszko, 1965). The observations on the esterases were contrary to those expected. There was little differentiation among stocks within a syngen. This suggests that in nature selection for certain esterase genotypes must be high.

Since intrasyngenic variation is rare, it is possible to make comparisons among syngens and to assess intersyngenic relationships. The differences among syngens appear to be complex and affect several types of esterases. This implies that several gene differences are involved. A similar conclusion may be inferred from the data obtained by Tait (1970a).

Syngens differ from each other to different extents in their esterase isozymes. It 
was of interest to us that syngens with similar isozymes tended to be those which have been shown to attempt intersyngenic mating and which are similar in their mating-type and serotype inheritance. Syngens 4 and 8 belong to "group B" in terms of their matingtype inheritance, share common antigens, and can mate (see Sonneborn, 1957). These syngens also have esterases which set them apart from the other syngens. Syngens 1, 3, and 5 belong to "group A" in terms of mating-type inheritance; 1 and 3 have similar antigens, and syngen 1 can mate with either 3 or 5 . They also have esterase isozymes which appear to be indistinguishable. Syngens 1 and 5 were also found to have the same types of mitochondrial enzymes and could not be differentiated (Tait, 1970a). Thus, the isozyme technique confirms relationships of syngens which have been inferred from biological and other criteria.

If, however, we look deeper into the relationships suggested by mating-type and serotype inheritance, etc., some of these groupings may become less distinct as a result of what is learned from comparisons of isozymes. The syngens have been classified into three groups on the basis of mating-type inheritance. Group A includes syngens $1,3,5,9$, and 11; group B includes 2, 4, 6, 7, 8, 10, 12, and 14; group C has one member --syngen 13 (Sonneborn, 1957, 1966). The serotypes of syngens 4 and 8 were found to be more similar to each other than to that of syngen 2, but this group was set apart from syngens 1 and 3 (with closest affinity) and 9. Sonneborn (1957) concluded that there was an ancient evolutionary division of the syngens into two (or three) groups and suggested that syngen 1 gave rise to syngens $3,5,7,9$, and 11 , and syngen 4 to 8 and 10 .

Although much more information needs to be obtained, the results so far on different isozymes (our results and those of Tait) suggest more complicated relationships among the syngens. Some syngens do appear to be more closely related than others, but whether the syngens can be divided up into two or three groups seems an oversimplification. Each type of enzyme seems to vary independently, and the variations are distributed in a complex way among the syngens. It may be possible to measure evolutionary distance by totaling the number of differences between pairs of syngens and fitting the syngens into a multi-dimensional matrix. From this matrix it might then be possible to reconstruct the evolutionary history of the syngens.

But before this game is played, stocks grown on axenic medium need to be surveyed. The next paper (Rowe et al., 1971) deals with the problem of bacterial esterases and presents a comparison of the esterases of paramecia grown on bacterized and axenic medium. In the last paper of this series (Allen and Gibson, 1971), we report the results obtained so far on axenic stocks.

\section{ACKNOWLEDGMENTS}

We would like to thank T. M. Sonneborn, Myrtle Schneller, and other associates and students at Indiana University who enthusiastically gave us moral support and assistance in the initial phases of this research. The results reported in this paper were obtained on extracts made at Indiana and electrophoresed at Michigan. We are grateful to Sharon L. Weremiuk (University of Michigan), who assisted us in the electrophoresis, and to Mr. Louis Martonyi (University of Michigan), who suffered patiently through the photography of some 100 gels. 


\section{REFERENCES}

Allen, S. L. (1964). The esterase isozymes of Tetrahymena: Their distribution in isolated cellular components and their behavior during the growth cycle. J. Exptl. Zool. 155: 349.

Allen, S. L. (1968). Genetic and epigenetic control of several isozymic systems in Tetrahymena. Ann. N.Y. Acad. Sci. 151: 190.

Allen, S. L., and Gibson, I. (1971). Intersyngenic variations in the esterases of axenic stocks of Paramecium aurelia. Biochem. Genet. 5: 161.

Allen, S. L., and Weremiuk, S. L. (1971). Intersyngenic variations in the esterases and acid phosphatases of Tetrahymena pyriformis. Biochem. Genet. 5: 119.

Allen, S. L., Misch, M. S., and Morrison, B. M. (1963). Variation in the electrophoretically separated acid phosphatases of Tetrahymena. J. Histochem. Cytochem. 11: 706.

Beckman, L. (1966). Isozyme variations in man. In Beckman, L., and Hauge, M. (eds.), Monographs In Human Genetics, Vol. 1, S. Karger, New York, 75 pp.

Dryl, S. (1959). Antigenic transformation in Paramecium aurelia after homologous antiserum treatment during autogamy and conjugation. J. Protozool. 6 (suppl.): 25 (abst.).

Kościuszko, H. (1965). Karyologic and genetic investigations in syngen 1 of Paramecium aurelia. Folia Biol. 13: 339.

Rafalko, M., and Sonneborn, T. M. (1959). A new syngen (13) of Paramecium aurelia consisting of stocks from Mexico, France and Madagascar. J. Protozool. 6 (suppl.): 30.

Rowe, E., Gibson, I., and Cavill, A. (1971). The effects of growth conditions on the esterases of Paramecium aurelia. Biochem. Genet. 5: 151.

Sonneborn, T. M. (1957). Breeding systems, reproductive methods and species problems in protozoa. In Mayr, E. (ed.), The Species Problem, Am. Assoc. Adv. Sci. Symp., Washington, D.C., pp. $155-324$.

Sonneborn, T. M. (1958). Classification of syngens of the Paramecium aurelia-multimicronucleatum complex. J. Protozool. 5 (suppl.): 17.

Sonneborn, T. M. (1966). A non-conformist genetic system in Paramecium aurelia, Am. Zoologist 6: 589.

Sonneborn, T. M., Schneller, M. V., Mueller, J. A., and Holzman, H. E. (1959). Extensions of the ranges of certain syngens of Paramecium aurelia. J. Protozool. 6 (suppl.): 31.

Tait, A. (1968). Genetic control of $\beta$-hydroxybutyrate dehydrogenase in Paramecium aurelia. Nature 219: 941.

Tait, A. (1970a). Enzyme variation between syngens in Paramecium aurelia. Biochem. Genet. 4: 461.

Tait, A. (1970b). Genetics of NADP-dependent isocitrate dehydrogenase in Paramecium aurelia. Nature 225: 181. 